\title{
Echinococcus multilocularis in musk rat (Ondatra zibethicus): the first finding of the parasite in naturally infected rodent in the Slovak Republic
}

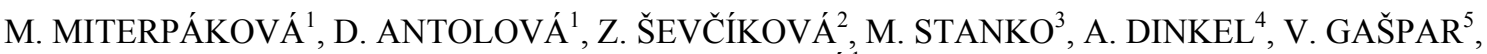 \\ P. DUBINSKÝ ${ }^{1}$
}

\begin{abstract}
${ }^{1}$ Parasitological Institute of the Slovak Academy of Sciences, Hlinkova 3, 04001 Košice, Slovak Republic, E-mail: miterpak@saske.sk; ${ }^{2}$ Department of Pathological Anatomy, University of Veterinary Medicine, Komenského 73, 040 01 Košice, Slovak Republic; ${ }^{3}$ Zoological Institute of the Slovak Academy of Sciences, Löfflerova 10, 04002 Košice, Slovak Republic; ${ }^{4}$ Department of Parasitology, University of Hohenheim, Emil-Wolff-Str. 34, 70599 Stuttgart, Germany; ${ }^{5}$ District Veterinary and Food Administration of the Slovak Republic, Levočská 112, 08001 Prešov,
\end{abstract} Slovak Republic

\begin{abstract}
Summary
Infection with the larval stage of Echinococcus multilocularis was diagnosed in musk rat (Ondatra zibethicus) in the Slovak Republic. At necropsy, massively enlarged liver with numbers of abscess-like lesions up to $1.5 \mathrm{~cm}$ in diameter was found. Histological examination shoved the presence of typical multivesicular cysts with multiple protoscoleces and typical laminated layer. Polymerase chain reaction confirmed the diagnosis. According to our knowledge, this is the first documentation of Echinococcus multilocularis in naturally infected rodent in territory of the Slovak Republic.
\end{abstract}

Key words: Echinococcus multilocularis; intermediate hosts; Musk rat (Ondatra zibethicus); Slovak Republic

\section{Introduction}

Alveolar echinococcosis caused by the larval stage of the fox tapeworm Echinococcus multilocularis, is the one of the most dangerous zoonoses in man. The geographical position of Slovakia provides suitable conditions for transmission and spread of this zoonosis which presents a topical health and veterinary problem (Turčeková et al., 2004). The natural cycle predominantly involves foxes, but also other carnivores as definitive hosts and many species of rodents as intermediate hosts. Humans and other mammals as accidental hosts, which do not play role in the transmission of the parasite, may be infected. In Slovakia, E. multilocularis was for the first time detected in red foxes in 1999 (Dubinský et al., 1999). Recent studies have shown the presence of the parasite in all districts of the country (Miterpáková et al., 2003). High-endemic foci with an estimated prevalence of more than $60 \%$ in some districts were detected in northern part of the country (Žilina and Prešov regions). Also the first five cases of autochthonous alveolar echinococcosis in the Slovak Republic were diagnosed from 2001 in patients living in districts of northern and central parts of the country distinguished by the highest prevalence and mean worm burden of E. multilocularis in foxes (Kinčeková et al., 2001, 2002, 2005). Despite the high prevalence in the definitive hosts, infection rate in voles, the main intermediate hosts, is relatively low in general $(<1 \%)$ (Viel et al., 1999). But it is thought that the foxes eat enough number of voles necessary to maintain the life cycle of E. multilocularis, because the foxes prefer voles as the main foods. The main aim of this study was to investigate small mammals for the presence of E. multilocularis larval stage and provide the evidence for the existence of a complete natural cycle of the tapeworm in the territory of the Slovak Republic.

\section{Material and Methods}

Between the October 2002 and October 2005 totally 452 small mammals coming from different areas of Košice and Prešov regions were investigated for the presence of larval stages of E. multilocularis. Animals belonged to 12 species, namely Apodemus agrarius - striped field mouse (Pallas, 1711), Apodemus flavicollis - yellow-necked mouse (Melchior, 1834), Apodemus microps - pygmy field mouse (Kratochvíl \& Rosický, 1952), Mus musculus house mouse (Linaeus, 1758), Rattus norvegicus - brown rat (Berkenhout, 1769), Clethrionomys glareolus - bank vole (Schreber, 1780), Microtus arvalis - common vole (Pallas, 1778), Pitymys subterraneus - common pine vole (de Sélys-Longchaps, 1836) Ondatra zibethicus - musk rat (Linnaeus, 1766), Sorex arraneus - common shrew (Linnaeus, 1758), Sorex minutus - pygmy shrew (Linnaeus, 1766), and Neomys fodiens - water shrew (Pennant, 1771). The livers of animals were examined macroscopically for 
the presence of the cysts. Cysts found were resected and divided into three parts. Small pieces of the lesions were compress between two glass slides and examined under microscope. The second part was fixed in $4 \%$ formaldehyde and subsequently examined histologically using haematoxylin-eosin staining. The third part was preserved in $70 \%$ ethanol. DNA was isolated and then amplified by nested PCR according to Dinkel (1998). Shortly, samples from liver lesions were digested in mixture of digestive solution (10 mM Tris $\mathrm{HCl}, \mathrm{pH} 7.5 ; 10$ mM EDTA, pH 8.0; $50 \mathrm{mM} \mathrm{NaCl} ; 2 \% \mathrm{SDS}, \mathrm{pH} 7.5)$, proteinase $\mathrm{K}$ and dithio threitol. After extraction with phenol-chloroform-isoamyl alcohol (25:24:1) DNA was precipitated with ethanol and 3 $\mathrm{M}$ sodium acetate at $-20^{\circ} \mathrm{C}$. Following drying, DNA was suspended in $200 \mu \mathrm{l} \mathrm{PCR}$ water. The target sequence for amplification is part of E. multilocularis mitochondrial $12 \mathrm{~S}$ rRNA gene. The PCR was conducted in two steps. For the first PCR, the primer pair P60.for and P375.rev was used. In a second step, the primer pair Pnest.for and Pnest. rev was used for nested PCR. After amplification, $10 \mu \mathrm{l}$ of PCR products was visualised on a $1.5 \%$ agarose gel containing $1 \mu \mathrm{g} \cdot \mathrm{ml}^{-1}$ ethidium bromide.

Table 1. Species composition of small mammals investigated for alveolar echinococcosis

\begin{tabular}{lccc}
\hline Order & Species & Investigated & Infected \\
\hline & Apodemus agrarius & 245 & 0 \\
& Apodemus flavicollis & 72 & 0 \\
Rodentia & Apodemus microps & 23 & 0 \\
& Mus musculus & 2 & 0 \\
& Rattus norvegicus & 15 & 0 \\
& Clethrionomys glareolus & 46 & 0 \\
& Microtus arvalis & 12 & 1 \\
Ondatra zibethicus & 23 & 0 & 0 \\
Insectivora & Sorex araneus & 10 & 0 \\
& Sorex minutus & 1 & 0 \\
Total & Pitymys subterraneus & 2 & 1 \\
\hline
\end{tabular}

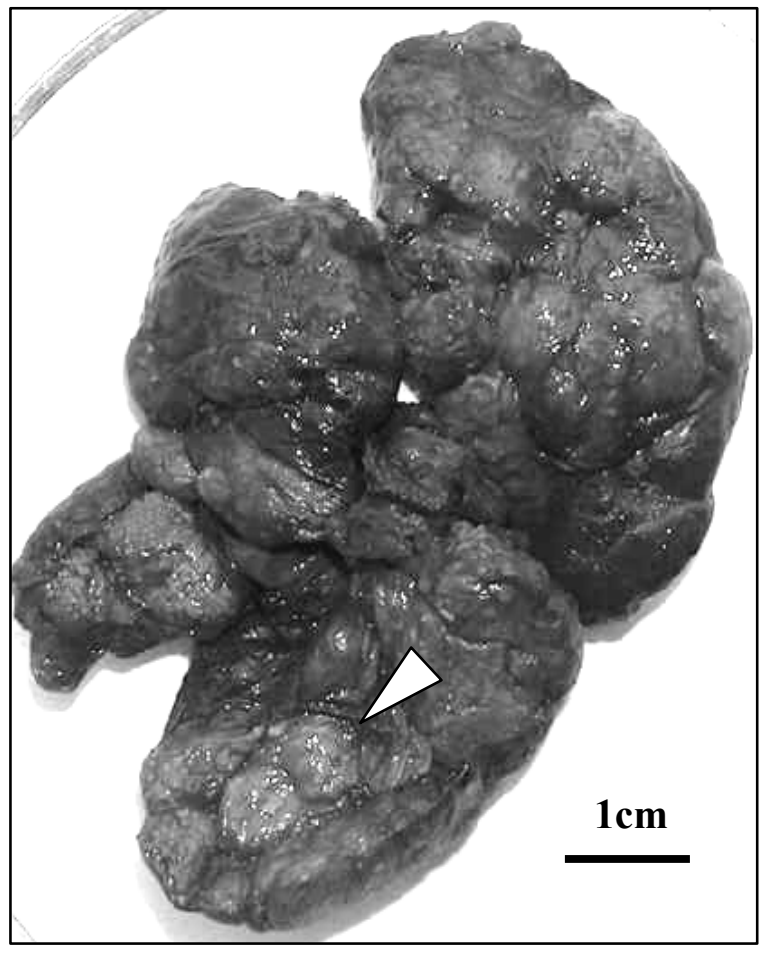

Fig. 1. Pathological findings. Enlarged liver from the musk rat with numbers of cysts (arrow) caused by Echinococcus multilocularis

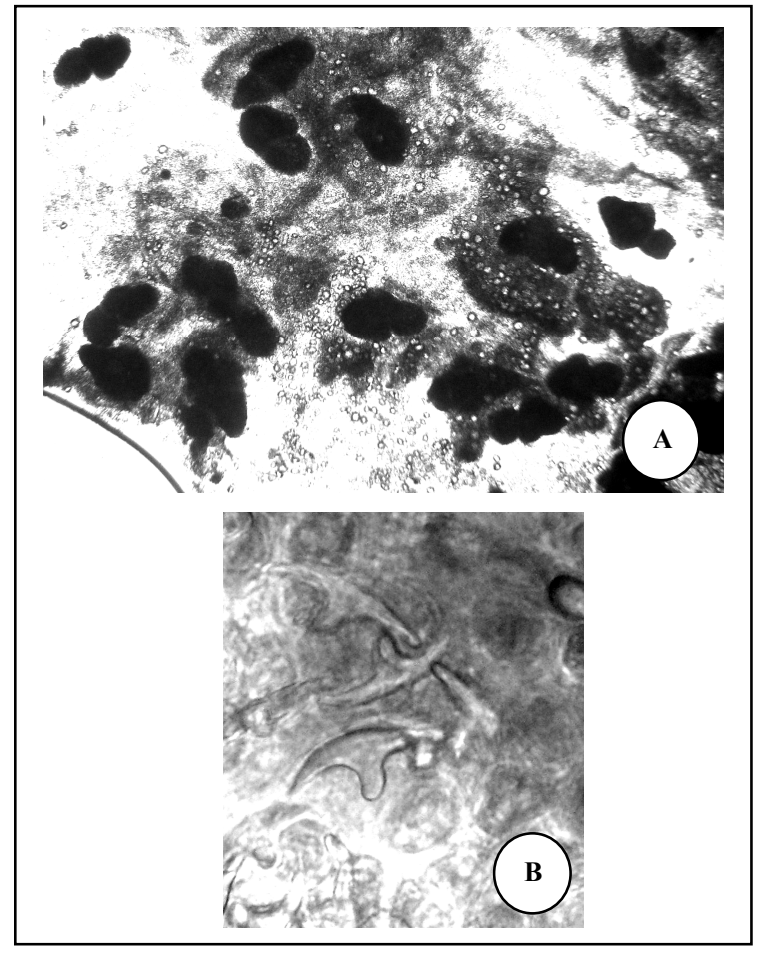

Fig. 2. Microscopically, protoscoleces $(63 \times)($ A) and protoscolexhooks $(200 \times)(B)$ were found in compressed tissue of liver lesions 


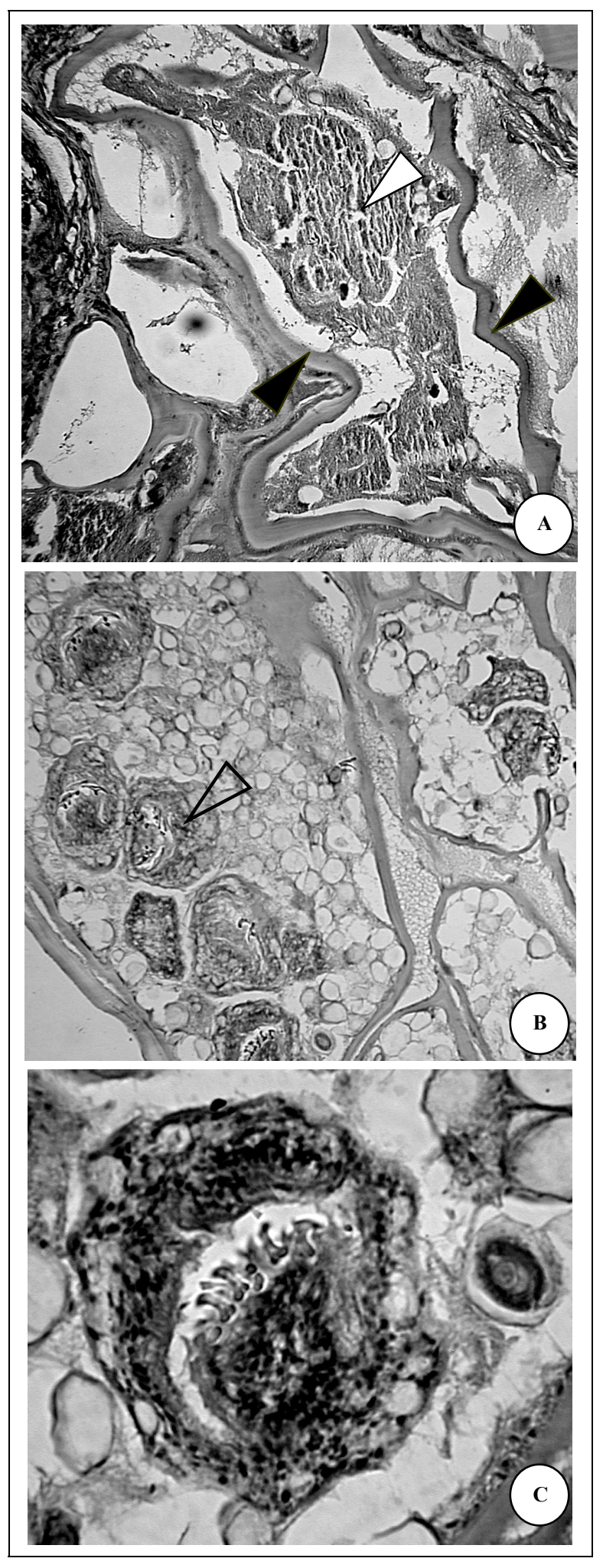

Fig. 3. A, B - Histological findings. Multilocular cysts of Echinococcus multilocularis with hyalinized laminated membranes (arrow heads) and necrosis (white head) (3A) and protoscoleces in the cysts $(3 \mathrm{~B})$ (open triangles). HE stain $\times 200$; $\mathrm{C}-$ Higher magnification of the protoscolex in the cyst with incomplete chain of hooklets. HE stain $\times 400(3 \mathrm{C})$

\section{Results}

Out of 452 small mammals examined (Table 1) only one musk rat (Ondatra zibethicus) was harbouring Echinococcus multilocularis metacestode in its liver. Positive animal originated from natural locality of the river Torysa near Seniakovce village (Prešov district). Macroscopically, the liver was massively enlarged and whole surface was covered with abscess-like lesions up to $1.5 \mathrm{~cm}$ in diameter. The whole parenchyma was fulfilled with numerous cysts protuberant above the liver surface (Fig. 1). In compressed pieces of the lesions, high number of protoscoleces and protoscolex-hooks were found under the microscope (Fig. $2 \mathrm{a}, \mathrm{b})$. Histological examination revealed the presence of multivesicular cysts with typical outer laminated layer. In some cysts the necrosis was observed (Fig. 3a). Granulomatous reaction was evident in the periphery of the lesions, accompanied by marked inflammatory cell infiltration. Numbers of protoscoleces were recognized in the majority of the sectioned cysts (Fig. 3b, c). Diagnosis was confirmed using nested PCR in which the part of E. multilocularis mitochondrial 12S rRNA gene $(250 \mathrm{bp})$, isolated from the liver lesions, was amplified (Fig. 4).

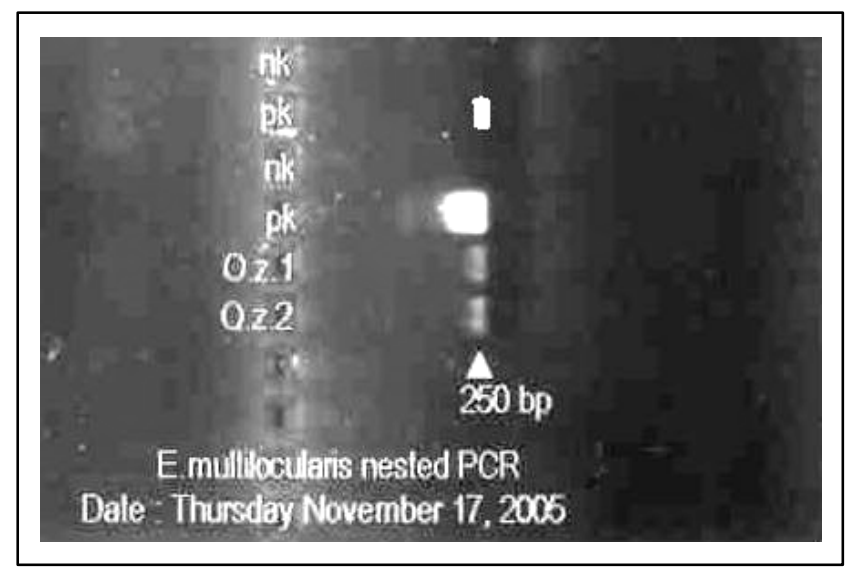

Fig. 4. Results of PCR examination of musk rat liver lesion (O. z. 1 - sample 1 of Ondatra zibethicus liver lesion, O. z. 2 sample 2 of Ondatra zibethicus liver lesion, nk - negative control, $\mathrm{pk}$ - positive control)

\section{Discussion}

Circulation of helminthes in biocenosis is provided by biological peculiarities of helminthes themselves, their intermediate and final hosts, as well as a number of other components of biocenosis, which are not directly involved in the parasitic life cycles (Anisimova, 2004). Data about the occurrence of E. multilocularis in intermediate host are different; its prevalence varies between $1 \%$ (Sikó-Barabasi et al., 1995; Martínek et al., 1998; Eckert et al., 2001) and $39 \%$ (Gottstein et al., 1996). These differences are influenced by the locality in which the observation was realized. Prevalence of alveolar echinococcosis found out in extended surveys provided on big areas was lower than 
those observed in high endemic areas. Density of small mammals in their natural environment is not regular. Localities with a higher density of rodents are more frequently visited by red foxes what results in accumulation of their faeces containing parasite eggs in such places. These eggs present the source of infection for other intermediate hosts. The formation of endemic locality is influenced by microclimatic conditions (humidity, temperature) which are optimal for cestode eggs survival. This suggestion was confirmed by Hansen et al. (2004) which observed that infected intermediate host occurrence correlates with the presence of conditions appropriate for egg survival.

In our study the majority of animals examined were belonged to the Apodemus genus that according to Rausch (1986), seems to be not a suitable intermediate host for $E$. multilocularis. On the other hand, Brzleg and Krystufek (1984) detected alveolar echinococcosis in a specimen from Apodemus flavicollis, and Dinkel in 1998 underwrote E. multilocularis infection in 6 individuals of Apodemus flavicollis and in 8 specimens of Apodemus sylvaticus by PCR. Wherefore Apodemus genus was included into our investigation.

Musk rat (Ondatra zibethicus), the only positive animal in the study, is a frequent intermediate host of E. multilocularis. Ondatra zibethicus is not endemic to Slovakia. It was transported to the former Czechoslovakia from North America in 1905. It has successfully adapted to live here and the speed of it expansion represented about $90 \mathrm{~km}$ within a year. In 1932 the whole territory of Slovakia was colonised by this animal species (Nowak, 1977). According to Forest Research Institute approximately $260-540$ musk rats are hunted per year (http://fris.sk/sk). In Europe, positive musk rats were for the first time observed in Germany in Badden-Württemberg region in 1981 (Frank \& Zeyhle, 1981). This time 8 out of 437 animals investigated were found to be positive. Later studies from this region showed dramatic increase of alveolar echinococcosis in musk rats (Romig et al., 1999). Infected animals were also detected by Keyhole et al. (1990) in Germany and by Borgsteede et al. (2003) in Netherlands. The number of investigated musk rats in territory of Slovakia is too low to highlight the epidemiological role of this species in the life cycle of Echinococcus multilocularis. However, several factors point to the importance of musk rat as an important vector in the spread of the tapeworm: musk rats are easy available for survey, particularly in regions with rich sources of water; musk rat is known to travel for long distances with the potential spread of the parasite; it is favourite prey species for red fox and racoon dogs; when hunted, it can transmit the parasite to man through dog infection. Additionally, musk rat is optimal species for monitoring of echinococcosis in intermediate hosts, because of its longevity comparing with other small mammals species.

Positive musk rat recorded in our study came from the natural locality of the river Torysa in Prešov district. Prešov region, together with Žilina region, was recognized to be locality with the highest prevalence and the highest infection intensity of E. multilocularis in red foxes. Prevalence rate reached here $56.9 \%$ in 2001 and $44.4 \%$ in 2002 (Miterpáková et al., 2003). Similarly, high correlation between prevalence of E. multilocularis in musk rats and in foxes was determined by Ewald (1990). Both mentioned districts of Slovakia are situated on the north of the country and are characterized by the lowest mean annual air temperature (4 $\left.-7^{\circ} \mathrm{C}\right)$, high mean annual precipitations $(700-1300 \mathrm{~mm})$ and low mean annual soil surface temperature $\left(3-7^{\circ} \mathrm{C}\right)$. Soil in northern Slovakia is mainly loamy and it is characterized by high humidity. The soil attributes seem to be very important for the survival of the oncospheres of the tapeworm. Areas like these, are very suitable for a formation and existence of high-endemic micro-focuses, in which parasite circulates between the definitive and intermediate hosts.

\section{Acknowledgement}

We are very grateful to Dr. Mošanský and Dr. Fričová for their help in field.

The investigation was supported by the Science Grant Agency VEGA 2/4179/04, the Science and Technology Assistance Agency under the contract No. APVT-51010704 and DAAD/SAS 2005-2006, No. 201/04.

\section{References}

Anisimova, E. I. (2004): Study on the European mink $M u$ stela lutreola helminthocenoses in connection with American mink $M$. vison expansion in Belarus: story of the study and review of the results. Helminthologia, 41: 193-196 Borgsteede, F. H. M, TiBben, J. H., VAN DER GiESEN, J. W. B. (2003): The musk rat (Ondatra zibethicus) as intermediate host of cestodes in the Netherlands. Vet. Parasitol., 117: 29 - 36

BRZLEG, J., KRYZSTUFEK, B. (1984): Echinococcus multilocularis (Leuckart, 1863) Vogel, 1955, metacestode in Apodemus flavicollis (Melchior) in Slovenia. Zb. Biotehn. fak. Univ. E. Kardelja, Vet., 21: 173 - 176

DINKEL, A. (1998): Spezifischer Nachweis von Echinococcus multilocularis - DNA aus End- und Zwischenwirten. Dissertation Universität Hohenheim, Stuttgart, Germany DubinskÝ, P., SVOBOdOVÁ, V., TURČEKOVÁ, L., LiTERÁK, I., MARTíneK, K., ReITEROVÁ, K., KOLÁŘOVÁ, L., KLIMEŠ, J., MRLíK, V. (1999): Echinococcus multilocularis in Slovak Republic: the first record in red foxes (Vulpes vulpes). Helminthologia, 36: 105 - 110

Eckert, J., Gemmel, M., Meslin, F. X., PAwlowski, Z. S. (2001): WHO/OIE Manual of Echinococcosis in Humans and Animals: Public Health Problem of Global Concern. $O I E$ and $W H O$, Paris

Ewald, D. (1990): Die Verbreitung des Fuchsbandwurmes Echinococcus multilocularis bei Fuchs (Vulpes vulpes) und Bisam (Ondatra zibethicus) im regierbezirk Freiburg. Mitt. Bad. Landesverb. Naturkunde u. Naturschutz, 15: 81 - 99 FOREST RESEARCH INSTITUTE (2003): http://fris.sk/sk FRANK, B., ZEYHLE, E. (1981): Echinokokken- und andere Bandwurmlarven im Bisam (Ondatra zibethicus). Nach- 
richtenbl. Deutsch. Pflanzenschutzd., 33: 166 - 170

Gottstein, B., Saucy, F., Wyss, C., Siegenthaler, M., JACQUIER, P., SCHMIDT, M., BROSSARD, M., DEMIERRE, G. (1996): Investigations on a Swiss area highly endemic for Echinococcus multilocularis. Appl. Parasitol., 37: 129 136

Hansen, F., Jeltsch, F., Tackmann, K., Staubach, C., THulKe, H. H. (2004): Process leading to a spatial aggregation of Echinococcus multilocularis in its natural intermediate host Microtus arvalis. Int. J. Parasitol., 34: 37 44

KinČeková, J., Auer, H., Reiterová, K., DubinskÝ, P., Szilágyiová, M., LAuKo, L., AsPöcK, H. (2001): The first case of autochtonous human alveolar echinococcosis in the Slovak Republic (case report). Mitt. Österr. Ges. Tropenmed. Parasitol., 23: $33-38$

KinČEKOVÁ, J., ReITEROVÁ, K., DubinskÝ, P., SzILÁGYIOVÁ, JohanES, R., GotTAS, M. (2002): A second case of autochtonous human alveolar echinococcosis in the Slovak Republic. Helminthologia, 39: 193 - 196

KinČEKOvÁ J., DubinskÝ P., DVOROŽŇÁKOVÁ E., AuER H., HudÁČKOVÁ J., DaŇOVÁ M., Stanislayová M., STRAKA L. (2005): Occurrence, classification and diagnostics of human alveolar echinococcosis in Slovakia. Czech and Slovak Gastroenterology and Hepatology, 59: 11 - 16 MartíneK, K., KolÁŘovÁ, L., ČervenÝ, J., ANDrEAs, M. (1998): Echinococcus multilocularis (Cestoda: Taenidae) in the Czech Republic: the first detection of metacestodes in a naturally infected rodent. Folia Parasitol., 45: 332 333

MiterpákovÁ, M., DubinskÝ, P., ReITERovÁ, K., MACH-
KOVÁ, N., VÁRAdY, M., ŠNÁBEL, V. (2003): Spatial and temporal analysis of the Echinococcus multilocularis occurrence in the Slovak Republic. Helminthologia, 40: 217 $-226$

NowAK, E. (1977): Ausbreitung der Tiere. Neue BrehmBücherei, A. Ziemsen Verlag, Wittenberg- Luthersatdt

RAUSCH, R. L. (1986): Life-cycle pattern and geographic distribution of Echinococcus species. In THOMPSON, R. C. A. (Ed.): The Biology of Echinococcus and Hydatid disease. Allen \& Unwin, London

Romig, T., Bilger, B., Dinkel, A., Merli, M., MACKenSTEDT, U. (1999): Echinococcus multilocularis in animal hosts: new data from Western Europe. Helminthologia, 36: $185-191$

SiKÓ-BARABÁSI, S., BoKor, E., FeKeÁs, É., Nemes, I., MurAi, É., GUBÁNYI, A. (1995): Occurrence and epidemiology of Echinococcus granulosus and E. multilocularis in the Covasna County, East Carpathian Mountains, Romania. Parasitologia Hungarica, 28: 43 - 56

TuRČEKOVÁ, L., KINČEKOVÁ, J., REgENSBOgENOVÁ, M., ReITEROVÁ, K., DUBINSKÝ, P. (2004): Immunochemical analysis of Echinococcus granulosus and Echinococcus multilocularis antigens. Helminthologia, 41: 179 - 183

VIEL, J. F., GiRAUdOUX, P., ABRIAL, V., BRESSON-HADNI, S. (1999): Water vole (Arvicola terrestris Scherman) density as risk factor for human alveolar echinococcosis. Am. J. Trop. Med. Hyg., 61: 559-565

ZEYHLE, E., ABEL. M., FrANK, W. (1990): Epidemiological studies on the occurrence of Echinococcus multilocularis in definitive and intermediate hosts in Germany. Mitt. Österr. Ges. Tropenmed. Parasitol., 12: $221-232$ 